\title{
Visualizing the Passion in Andrés de Li's Summa de paciencia
}

\author{
ISIDRO J. RIVERA
}

THE UNIVERSITY OF KANSAS

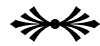

Religion, like art, lives in so far as it is performed. -Victor Turner, The Anthropology of Performance
\end{abstract}

Para Jessica Ann Melhuse

\section{Introduction}

$\mathrm{T}$ he sole pictorial element in the 1505 Summa de paciencia (henceforth $S d P$ ) contains a single, full-page image of Christ as the Man of Sorrows, also known as the Imago pietatis (see image). ${ }^{1}$ Located on the verso of the first folio, the printed image of the suffering Christ should cause the readers to pause and reflect on the relationship of this illustration to the work they are about to read. The text neither references the image, nor does it give its readers any indication of its purpose. In many cases, devotional images such as this one would have been as important as the text it accompanied (Duffy, Marking the Hours 11-12). Similar printed illustrations from the period served as staging points for devotional activity and were elements actively used by the owners of the text to enrich their religiosity and piety. ${ }^{2}$

Through this visual paratext, the $S d P$ draws the reader's attention to the mystery of Christ's Passion, a topic that does not always play a prominent role in medieval treatises on Patience. ${ }^{3}$ This image's placement on the verso of the title

\footnotetext{
${ }^{1}$ The $S d P$ published by Jorge Coci in Zaragoza survives in a pristine exemplar housed in the collection of the Biblioteca Universitaria, Universidad de Zaragoza, shelfmark An-7-5-14. In the course of preparing this study, I have consulted the 1493 Zaragoza princeps attested by the exemplar in the Library of El Escorial, shelfmark 31-V-47. The extant witnesses for the 1493 edition that I have examined are lacking the first folio, which presumably would have contained the title page on the recto and a woodcut illustration on the verso. I owe a debt of gratitude to Marcelino de Otero for his assistance with the Escorial incunable. My description of the woodcut page relies on the unique 1505 exemplar housed in the Biblioteca Universitaria, Zaragoza.

${ }^{2}$ Two examples of this type of woodcut placement can be found in: Thesoro dela Passion (Zaragoza: Hurus, 1494, A1v, Library of Congress), and in La passion del eterno principe (Burgos: Fadrique de Basilea, 1493, folio 1v, Boston Public Library).

${ }^{3}$ Hanna has isolated four topics that concern late medieval discussions of Patience: acts of the patient man, cause for which the patient man suffers, external situations in which the virtue proves useful, and mental qualities associated with the virtue (68-76).
} 


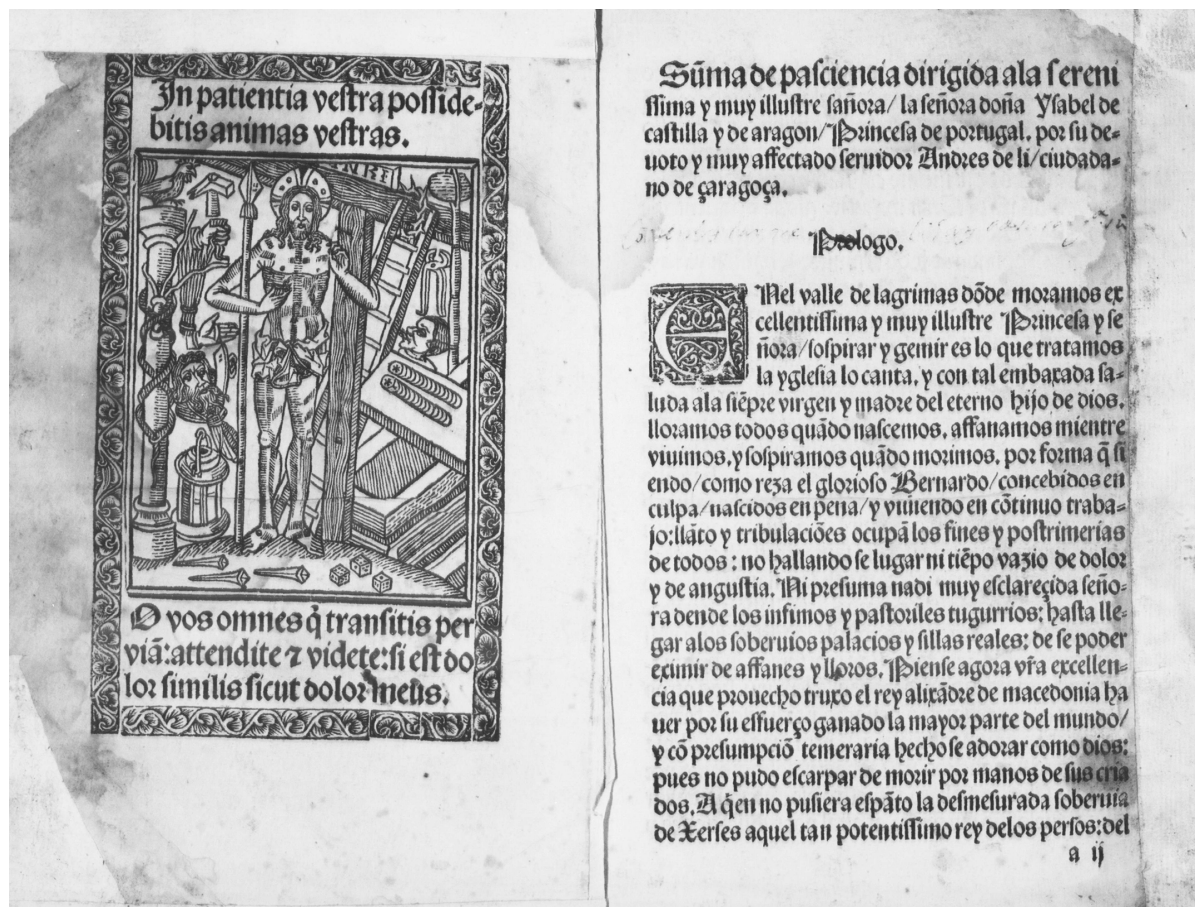

Woodcut page and "Prologo" from Andrés de Li, Summa de paciencia (Zaragoza: Jorge Coci, 1505. A1v-A2r). Courtesy of the Biblioteca Universitaria, Universidad de Zaragoza, Spain.

page and adjacent to the "Prologo" gives the page a privileged status. It would have been the first large paratextual element noticed by the readers. The fullpage depiction of Christ emerging from the sepulcher, half-naked with the wounds of his Passion, is an iconic pose intended to cause the viewers to remember the key events of Christ's suffering and death. In this version, the figure of Christ stands with arms around the lance and the cross with its titulus and looks out with gestures that seem to beckon the spectator. The 1505 page also contains representations of the instruments of Christ's torture, the so-called arma Christi: an open sarcophagus, a ladder, a rooster, the dice used to divide Christ's robe, a spitting face, clothing, the column of the Flagellation, nails, and other instruments of his torture and death. These emblematic elements constitute powerful reminders of the Passion and form "visual triggers to remind Christians of what God had suffered for them" (Bynum 18). Rosemary Woolf ascribes to this type of image a meditative function:

Reference to historical time is deliberately evaded: Christ is shown oppressed by suffering, although the Crucifixion is past, as the wounds in hands, feet, and side bear witness. No historical or dogmatic purpose is served by this representation. The intention is entirely meditative, to confront the beholder with a timelessly suffering Christ and thus to arouse his compassion. (185) 
The image with the embedded arma objects ultimately embodies a Christian aesthetic which represents "the horror of the Crucifixion" in order to confront the believer with the salvific potential of Christ's body (Bynum 18).

Late medieval and early modern readers of Li's $S d P$ approached the text through the Imago pietatis and came to understand Patience through a reflection on the Passion of Christ. While this approach touches on examples of Patience in the Bible and other Christian writings, from the moment the readers open the book the Passion becomes a central focus. In chapter 6, Li directs the readers to the Passion devotions: "Consideremos pues continuamente los enxemplos de tan santos varones: y parescer nos han liuianos de suffrir nuestros dolores. Y concluyendo con nuestro redemptor y maestro Jesu consolar nos podemos conlos oppobrios y tormentos de su santa passion" (B3v-B4r).$^{4}$ In this context, the text moves from the exemplarity of the Saints to the exploration of the Passion of Christ.

The deployment of this image conveys a significant Christocentric message, which Castilian readers of the period would have processed and would have used as a guide to their reading of Li's text. One of the characteristics of print was its privileging of image. Roger Chartier has suggested that "the image was often a proposal or a protocol for reading, suggesting to the reader a correct comprehension and a proper meaning for a text" ("Introduction" 5). While recent scholarship has characterized the $S d P$ as a "concordance of the many works on patience that preceded it" (Delbrugge 21), an examination of the Imago pietatis helps us to situate the $S d P$ within a larger religious discourse in which the meditation on Christ's suffering and death was a key component for achieving salvation: "por quanto por el discurso de nuestra obrezilla hauemos tuuido por cierto que las tribulaciones y temptaciones suffridas con paciencia son camino seguro para mereçer la gloria bienauenturada del cielo" (H3r).

One can also argue that in many ways Li's text offers the possibility of altering the self and giving it the ability to cope with the sufferings and hardships inflicted by the quotidian world. To understand the potential for transformation, I borrow Michel Foucault's concept of "technologies of the self," which postulates that individuals are able "to effect by their own means or with the help of others a certain number of operations on their own bodies and souls, thoughts, conduct, and way of being, so as to transform themselves in order to attain a certain state of happiness, purity, wisdom, perfection, or immortality" (18). This essay will explore how these transformations are actualized through the technologies of reading and visualization in Li's $S d P$. To approach the $S d P$ in this way is to discover how the interplay of visual and verbal codes ultimately directs the readers to interact with the Passion narrative in order to modify their subjectivity and effect spiritual growth.

\section{In patientia vestra possidebitis animas vestras (Luke 21:19)}

This quotation from Luke occupies the top register of the verso of folio 1 in the 1505 Zaragoza edition of $S d P$ and accompanies the Imago pietatis printed on that

${ }^{4}$ In this essay, I will cite and transcribe exclusively from the 1505 Zaragoza edition. In my transcription, I have expanded all abbreviations, respected the original orthography of the incunable, and utilized modern punctuation only where needed for the sake of clarity. 
page. At the bottom of the page, the reader finds a second verse from Lamentations 1:12: "O vos omnes qui transitis per viam attendite et videte: si est dolor similis sicut dolor meus" ("O all ye that pass by the way, attend, and see if there be any sorrow like to my sorrow"). Both verses, the first textual elements after the title page, provide scriptural anchoring for the larger theme of Christian Patience that permeates the $S d P$. The verses situate the readers within a tradition of meditation and reflection centered on the mysteries of the Passion. James Marrow ascribes the growth of these networks of religiosity to the efforts of the Franciscans, who transformed spirituality into "systems of private devotions" $(10) .5$

Late fifteenth-century Castile's interest in Christ-centered devotional activity was guided in part by the efforts of Fray Hernando de Talavera, Queen Isabel's confessor and spiritual advisor, who promoted religious practices that privileged personal and visual devotion. Talavera's Católica impugnación (c. 1480) provides an important document for understanding the importance of these devotional practices. In this treatise, Talavera urged: “queremos y ordenamos que cada fiel Cristiano tenga en la casa de su morada alguna imagen pintada de la cruz, en que nuestro Señor Jesucristo padeció, y algunas imágenes pintadas de nuestra Señora o de algunos santos o santas que provoquen y despierten a los que allí moran a haber devoción" (186). The requirement that images should function as stimuli for Passion-centered activities had far-ranging consequences in late fifteenth century Castile. While the rest of Europe had already embraced these types of devotions, its implementation in Castile was rather late. Cynthia Robinson has recently pointed out that Christocentric devotions "individual, somatic, or intimate relationships to Christ established through the use of "personalized' Passion imagery, whether actual or imagined, simply did not appear to have formed part of medieval Castilian devotional culture before the final decade of the fifteenth century" (Imagining the Passion 6). Talavera's recommendations produced a shift in the faithful's engagement with religious images that resulted in the cultivation of new devotional approaches to the Passion. Robinson, moreover, has made compelling arguments for establishing the period for the dawn of these practices and concludes that the last decade of the fifteenth century marks the emergence of this spiritual current: "the strongest advocation of new currents of devotion by Queen Isabel and her ecclesiastical counselors was concentrated in the final eight or nine years of the fifteenth century" (372).

This engagement with religious images and the promotion of new devotional activities produced significant changes in Castile. Felipe Pereda has described this engagement in terms of two trajectories. The first involves a movement from public domain to private space: "Las imágenes se desplazaron desde los altares al interior de los hogares, desde los templos a las celdas" (82). Pereda describes the second trajectory in terms of the importance of images in extraliturgical devotions: "las prácticas devocionales empezaron a conceder cada vez mayor importancia al elemento figurativo, tanto a los productos de la imaginación

${ }^{5}$ See Bestul for a discussion of devotional texts in late medieval Europe, especially 145-64. 
como a las pinturas o las esculturas que debían fomentarlas" (82-83). ${ }^{6}$ These cultural practices took hold during the Isabelline monarchy and developed as the Monarchy advocated a "multi-faceted movement for spiritual reform" (Lehfeldt 161). While these developments are most evident in the religious paintings and the visual arts of the period, as Robinson has detailed in her Imagining the Passion, the phenomenon also occurs in other modes of cultural production. This was certainly the case with books, where the production of religious texts accounted for $45 \%$ of the editorial output in Spain during this period. Pedraza Gracia has noted that during this same period, the output of religious texts reached $55.5 \%$ in Zaragoza (18). The advent of print especially supported these Passion-centered practices. Lay readers could utilize printed texts to fashion "a more personal form of piety, a more private devotion, a relation with the sacred not subject to the discipline and mediation of the Church" (Chartier, "The Practical Impact of Writing" 125). Print technology also facilitated the production and dissemination of images and textual materials in support of the Church's promotion of these practices.

$\mathrm{Li}$ was certainly aware of the religious climate and the potential for promoting these Christocentric activities via print. His Thesoro de la passion, published in Zaragoza one year after the princeps of the $S d P$, sought to rectify the lack of Passion meditations available to Castilian readers:

Et por no menos difícil denegar cosa tan justa [fol. 2v] y conosciesse por mayor el trabajo del que mis fuerças podían çufrir acorde de condescender a sus ruegos, tuuiendo por mejor afrontar los vayvenes et peligros delos parleros que encojer el provecho de los que no entendiendo en latin se gozaran conella en romançe, presuponiendo que muchos que occupauan a mas no poder sus ocios en leer cosas transitorias et vanas, recreando conel entender altos misterios dela passion sacratissima, no solo conuertiran en vtilidad, mas ahun aprovecharan a muchos otros en doctrina y enxemplos. (Li, A Scholarly Edition 92)

The editions of the Thesoro contained over 130 woodcut images that situated the readers as spectators of the events associated with Christ's torture and death.

In the $S d P, \mathrm{Li}$ is most likely aware of Talavera's incitement to practice devotions centered on the Passion of Christ. While the $S d P$ 's principal goal is to guide its readers through an examination of the Christian virtue of Patience and its associated virtues, the text additionally offers the readers a manual for reexperiencing the narrative of the Passion and establishing empathetic relationships with the suffering endured by Christ: "Y el principal es considerar y tener en memoria la passion santa de Cristo: por la qual somos justificados: ca ninguna culpa se podra fallar de tanta efficacia: ni tan digna de muerte eternal: que por la muerte de Cristo no sea librada" (G8v-H1r). It is noteworthy that Li refers to the Passion as a locus for memorial activities that the readers can use to under-

\footnotetext{
${ }^{6}$ For more information on private images in Iberia, see Peña 243-44. For the effects of the proliferation of printed images in early modern Europe, see Freedberg 174-78.
} 
stand the importance of Christ's death. This memory can be actualized verbally or visually, and the printed book supports both modalities.

The deployment by Jorge Coci, the printer, of a full-page depiction of the Man of Sorrows in the first folio responds to this religious environment in late medieval Castile. The iconic elements embedded in the cut derive from a Byzantine devotional image depicting a half-length Christ after the Resurrection popularized during the thirteenth century at the Basilica of Santa Croce in Gerusalemme in Rome. It subsequently spread throughout late medieval Europe as a devotional cult object and source for indulgences (Lewis 184-89; Swanson 232). According to one tradition, Pope Gregory had granted an indulgence of 14,000 years for devotions performed before this image (Parshall, "Imago" 557). The popularity of this image type grew in the last decade of the fifteenth century when the Carthusian Order mounted a campaign to promote pilgrimages to Santa Croce and encourage devotion to the Passion of Christ (Bertelli 49-52). This devotional image and the indulgences associated with this pictorial device entered Castile in the fifteenth century and formed part of a network of religious practices that offered the devout opportunities to gain salvation (Robinson, "Preaching to the Converted" 158-59). Parshall suggests that these processes also involved acts of "internal visualization, of image making" ("The Art of Memory" 466). The image would compel readers to visualize the scene depicted and imagine the significance of these sacred events. In the case of the 1505 Zaragoza edition, the woodcut would have a similar effect and connect the reader/viewer with a network of practices and devotional activities associated with this type of image.

The dissemination of this particular woodcut image in late medieval Castilian printed books also sheds light on its reception as a devotional image by readers in early sixteenth-century Iberia. This image originated in the Hurus workshop and circulated as an illustration used in the Aurea expositio hymnorum (Zaragoza, 1492), a commentary on sacred hymns. ${ }^{7}$ The image (E2v) accompanies the commentary on the Vexilla regis, a sixth-century Latin hymn associated with the Cross of Christ and traditionally sung in the Good Friday services. The image reappears in an Officia quotidiana, published in Zaragoza by Coci, Hutz, and Appenteger in $1500 .{ }^{8}$ Occupying the entire page, the cut precedes a series of Latin devotional prayers commonly known as the The Fifteen Oes, once attributed to Bridget of Sweden, but now thought to have been composed by an anonymous writer in England. ${ }^{9}$ The prayers encouraged imaginative contemplation of Christ's suffering and sought to produce in the readers affective responses to the Passion. A final example appears in a reprint by Coci of the Aurea expositio (Zaragoza, 151520).$^{10}$ The image in this edition also accompanies a commentary and meditation on the hymn Vexilla regis.

\footnotetext{
${ }^{7}$ I have examined the witness housed in the Real Biblioteca de Palacio, Madrid, shelfmark I/142, E2v.

${ }^{8}$ This witness is housed at the Biblioteca Nacional, Madrid, shelfmark, Inc 2724, fol. LXXIIIv.

${ }^{9}$ On the Oes, see Duffy, Stripping of the Altars 249-56. For the Oes in Castile, see Robinson, Imagining the Passion 117-18.

${ }^{10}$ I have consulted the witness at the Biblioteca Nacional, Madrid, shelfmark, Inc R/39638, E2r.
} 
Coci's choice of illustration reveals the varied functionality of this devotional image. He most likely acquired the image when he purchased the Hurus shop in 1499 and probably was aware of its reuse in other imprints. Since the recycling of woodcuts occurred frequently during the incunabular period, it should not surprise us that this devotional image bears similarities with religious hymns, prayers, and other sacred objects that would inform readers' horizons of expectations. ${ }^{11}$ As Stevenson has reminded us, medieval culture often "framed sacred objects as functioning like stage props, carrying with them traces of a devotional past that belonged to time and to mortality" (57). It is likely that Castilian readers would have responded in a similar fashion. The pictorial elements on the page would have inserted the printed book within a larger discourse of spirituality that would have prompted the readers to utilize the object as a vehicle for devotional activity.

The paratext on this page engages the readers in other ways. The verses selected to accompany the woodcut create a dialogue between the text and image. The pictorial and verbal in such close proximity allow the readers to establish links derived from specific devotional moments in their lived experiences of Christianity. While the printed image promoted a visual exploration of one of the central mysteries of the Christian religion, the act of reading this page also made possible a performative dimension. Clark and Sheingorn's comments concerning reading and performance are pertinent here: "The written word does not remain inert on the page; rather the act of reading transforms it into enacted text, and it is this process that we term performative reading" (136). The reading of this woodcut page, whether voiced or silent, alone or communal, would enable the readers to experience the liturgical within their personal realization of empathic spirituality. The performance of these sacred events would bring the readers into conformity with the devotional practices advocated by Li.

The verse from Lamentation would have been familiar to readers as one of the antiphons chanted during the Good Friday and Holy Saturday liturgies to summon the devotees to reflect on the suffering endured by Christ (Petersen; O'Kane 72). In addition, the verse from Luke formed part of the Commons of the Apostles, one of the litanies recited during the Easter Triduum. As a consequence, the paratext points to liturgical performances and religious spectacles most likely witnessed and remembered by the readers. In this context, Jessica Brantley has noted: "Through a variety of allusions to the conditions of performance, certain late medieval devotional texts call upon their readers to imagine public spectacles as a way of creating individual ones" (3). These experiences would have been internalized and would have provided triggers for activating affective responses to the Passion story.

With reference to the verse from Lamentation, Hans Belting has noted that it frequently appeared as a caption to the Imago pietatis during the medieval period (197). More significantly, the verse adds a performative dimension to the miseen-page. The exhortation to visualize ("videte") explicitly encourages the reader

${ }^{11}$ For a discussion of the reuse of woodcuts in Castile during the early years of printing, see the studies by Griffin and Lucía Megías. 
to reflect on and "make present" the pain endured by Christ. ${ }^{12}$ Given this context, upon viewing the image found on Alv, the readers would have been emotionally transported to this well-known moment during the Passion of Christ. The readers in turn see the resurrected Christ as both a suffering body and a speaking voice ("O vos omnes"). Looking and hearing were thus woven here to form a play-like tableau in which the readers must visualize the dramatic nature of these sacred events and realize a private, empathic engagement with the suffering and death of Christ, a goal subsequently endorsed by Li in the $S d P$. Through the contemplation of the page, the devout subject re-experiences the spectacle of the Passion. Felipe Pereda associates this type of activity with the emergence of a devotional culture that promoted affective responses to images ("experimentar empáticamente las imágenes" [37]).

Given this context, Coci and his artisans most likely designed this paratexual element to support Li's emphasis on the Passion narrative and Christocentric meditational processes. In turn, Coci's mise-en-page becomes a tool through which readers were able to effect a change in their spiritual life. The active contemplation of this page allowed the readers to acquire a richer understanding of Christian precepts and values. Amtower suggests that this process might result in the readers' discovery: "both literally in the sense that a reader might open him or herself to a vision of God or a saint through the reading act, and metaphorically, in the sense that one might perceive and understand worldly phenomena better by learning to read the signs" (50). This process contributes to the process of engagement and the possibility of transformation by means of the doctrines and mysteries of Christianity.

\section{Origo et magnitudo patientiae Deo auctore procedit (Cyprian of Carthage 3.8-9)}

As we have seen, the $1505 S d P$ directs the reader to reflect on the virtue of Patience through the context of the Passion. Within the Western Christian tradition, however, the discussion of Patience often takes a different tack. Robin Waugh in his study of "medieval patience literature" defines the genre as one that "features and praises, explicitly or implicitly, the 'ability to endure,' to keep on being the same person despite oppressive suffering" (7). This emphasis is pervasive in the earliest theological reflections on Patience. Cyprian of Carthage, whose third-century treatise De bono patientiae is an early example of writing on this topic, focuses on the exemplarity, sufferance, and forbearance of Biblical figures like Job, Tobias, Moses, and Abraham. More significantly, only 3 of 24 chapters in Cyprian's treatise center on the Passion. Cyprian's treatise closes with a discussion of Charity, Carnality, and Evil (31-41), topics that steer the text away from a Christocentric focus. Cyprian's approach influenced Church Fathers like Tertullian, Augustine, and Aquinas. According to Hauerwas and Pinches, most of the writings on the virtue of Patience by early theologians rooted their

\footnotetext{
${ }^{12}$ For an analysis of the "behold and see" convention in medieval drama, see Mills.
} 
discussion of Patience in the virtues of Faith, Hope and Charity, and not in the meditation on the Passion story (207-10).

The overall thematic structuring of the $S d P$ at first glance seems to be linked to the tradition of these treatises. Li's text indeed rehearses many of the concepts derived from these earlier discussions of Patience. He incorporates, for instance, allusions to Job, Tobias, and the saints in order to impart to his readers the value of cultivating Patience:

La segunda consideracion es meditar los enxemplos y vidas de los santos que passaron y son: assi como de job y tobias y otros del testamento viejo et infinitos del nueuo: reboluiendo muy amenudo por nuestra memoria las langostas y cilicio del santificado baptista: los trabajos y peligros de pablo: las vigilias de bartholome: el saco y el pan de jeronimo. ... (B3r-B3v)

Through active meditation on these enxemplos, readers would acquire a richer understanding of this virtue. In order to better comprehend the experience, one must keep in mind the individual readers' lived experience of Christianity and the Bible. According to Carruthers, meditative memories helped to "perfect one's soul ('perfect' in the sense of 'fill in,' inscribe things in all those empty tablets of memory)" (The Craft 31). These activities ultimately made possible the readers' attainment of knowledge that would enable them to fashion their lives within the framework of Christian life.

While Li's text does appropriate information from other writings on Patience, the distinctiveness of the $S d P$ resides in its departure from the traditional discussion of Christian Patience. As this study has shown, Li engages his readers in a series of exercises that promote the Passion as a tool for understanding the meaning of this virtue. Li both stresses "los enxemplos de tan santos varones" and steers the readers toward a focus on Christ through whom "consolar nos podemos conlos oppobrios y tormentos de su santa passion" (B4r). Li also exhorts the readers to become attentive to scripture: "ca por el leer entendemos y entendiendo gozamos delos secretos dela sagrada escriptura: la qual es reposo y consolacion delos tribulados" (A8v). Li often reminds the readers of the value of Christocentric reflection: "Y porende si la cruz y vestidos de nuestro maestro jesu son a nosotros marauillosas y muy estimadas reliquias contra toda temptacion y poçoña: quan sin comparacion deuen ser estimadas las tribulaciones y dolores de su passion sacratissima" (A8r). In this passage, Li anchors the discussion with a reference to "reliquias" and their functions as memorial devices that transport the devotees to key moments in the Passion. The relics, "la cruz y vestidos," are obviously intended to awaken remembrance of Christ's suffering and torture. These references dissolve the distance between the readers and the historical moment of the Passion.

Like the iconic objects displayed in the woodcut in A1v, these textual references create what Parshall has called "a segregated set of memory cues parsed out to recall specific moments" that would bring into the readers' memory key events already conditioned by liturgical and extraliturgical activities ("The Art of Memory" 464). As a consequence, Li's readers are given the opportunity to 
interact in an intimate and immediate fashion with the death and suffering of Christ. In some cases, this passage might awaken in the readers a memory of the illustration printed on the first folio. Its display of the Arma contains the "cruz y vestidos." In other cases, the reference to "cruz y vestidos" might evoke experiences internalized by an individual during liturgical activities associated with Christ's life-for example, the Good Friday liturgy. It is with this atmosphere in mind that one must approach Li's work in order to better understand how it appeals to the reader and connects the text with contemporary religious practices. Li's text weaves these verbal cues into a network of signs that allows readers to realize an improvement of their spiritual life. He later reminds the readers of the centrality of the Passion in their daily activity: "Por esso dize san pedro: hermanos: armemos nuestro pensamiento dela cogitacion continua dela passion santa de Cristo" (B4r). Through these activities, the reader is able to construct a subjectivity based on imaginative meditation ("cogitacion continua") on Christ's suffering, and thus attain the salvation, which is the goal of all Christians. This "cogitacion continua" would in turn comply with what Talavera implies are the devotional activities of "cada fiel Cristiano" (186).

Within this regimen, the visual and verbal reading of Li's book becomes a technology for spiritual enrichment that provides the reader with the skills to improve of the self. Through the routines proposed by Li, laypeople structured their day in imitation of clerical practices and sought to reap the benefits of spirituality and interiorized piety. Whether voiced or silent, alone or communal, these reading acts played an important role in the development of the devout subject's identity as a faithful adherent to the Christian faith.

Li's emphasis on imaginative meditation draws from the long-established practice of lectio divina introduced into the Western tradition by Cassian and Benedict (Fulton 156). Reading formed, according to Brian Stock, "steps . . by which the individual climbed toward perfection thought to represent complete understanding and effortless communication with God" (90). As Rachel Fulton has observed, the practice of lectio became "the basis for creating the spiritual self, much as eating created the physical" (156). In this context, Illich notes that lectio was also seen as "an act of worship at whose center stands the incarnation of wisdom" (50). Through this activity, readers were empowered to grow spiritually and to engage in processes that ultimately led to an intimate relationship with God. Geert Zerbolt, a fourteenth-century writer associated with the devotio moderna movement, viewed the process in the following manner: "By meditation is meant the process in which you diligently turn over in your heart whatsoever you have read or heard, earnestly ruminating the same and thereby enkindling your affections in some particular manner or enlightening your understanding" (qtd. in Gründler 182). In this setting, the layperson can utilize the knowledge gained through reading to achieve an understanding of how to attain personal salvation. Reading constituted the first step toward meditation and ultimately led the readers to prayer (Sterponi 671).

The $S d P$ outlines this precise regimen in chapter 5 . The chapter's title, "que leer: meditar: y orar: nos ayudan mucho para ser paçientes" (A8v), makes clear the importance of reading for Christians seeking to become practitioners of the virtue of Patience. $\mathrm{Li}$, in addition, uses this chapter to explore the larger dimen- 
sions of these activities: "ca si por esperiencia veemos que palabras de hombres son sufficientes para nos consolar: mucho mayor y mas crescido consuelo sera leer las palabras de dios: las quales alos tribulados pueden pascer de spiritual alegría como enlos prouerbios se reza: las palabras de dios es conorte a todos los que esperan enel" (A8v). The final component in the regimen proposed by $\mathrm{Li}$ is prayer, which functions to solidify and affirm Christian identity:

Si quieres con paciencia passar las cosas aduersa: ora. Si quieres concular las afficciones prauas ora. Si quieres conoscer las astucias del gran sathanas y euitar sus engaños ora. Si quieres enlas obras de dios biuir alegre y no dar lugar alas aflicciones ora. Si te quieres exercitar enlo espiritual: y oluidar el cuydado y desseos corporales ora. Si quieres echar de ti las cogitaciones vanas ora. Si desseas engordar el alma con sanctissimas deuociones ora. Si quieres firmar tu coraçon en constante proposito del seruicio de dios ora. Si quieres extirpar los vicios y enchir de virtudes ora. Si desseas subir en contemplacion ora. Si quieres sentir el dulçor delas cosas celestes y gustar las marauillas de dios ora. (B1r)

Li's insistence on the value of prayer is consistent with the practices of lectio. Time dedicated to reading sacred texts would lead the readers to fashion a life that imitates the lives of the saints, the disciples, and Jesus. ${ }^{13}$ Prayer would become the expression of assent, a desire to experience "el dulçor delas cosas celestes" (B1r).

While Li's formulation of the importance of prayer is consistent with medieval practices based on the routines of lectio, his words are a translation of a portion of chapter 36 of the Meditaciones vite Christi (henceforth MVC), a fourteenthcentury text, whose influence on European devotional literature and religious visual culture has been sizeable. ${ }^{14}$ Karnes characterizes the $M V C$ as a "training manual for the imagination even as it instructs the meditant in the value of meditating on Christ's life" (Imagination 172). Associated with Franciscan devotional practices, the $M V C$ survives in over two hundred manuscripts and was widely available in a number of translations. ${ }^{15}$ According to Boon, the $M V C$ had limited influence on Castile and its devotional practices (43). ${ }^{16}$ In the case of $S d P$, Li clearly has some familiarity with the $M V C$ and inserts the passage in the

\footnotetext{
${ }^{13}$ For an overview of this cultural concept, see Carruthers's The Book of Memory 156-88.

${ }^{14}$ This text is frequently attributed to Bonaventure. According to recent scholarship, however, the author was probably Johannes de Caulibus of San Gimignano, a Franciscan friar (Despres 34-41). Recently McNamer has suggested reconsideration of the attribution of authorship and the integrity of the texts ("The Origins"). For correspondences in medieval art, consult Mâle (26-48) and Flora. For $M V C$ s function as prayer book, see Meany.

${ }^{15}$ See the studies by Bryan, McNamer, and Karnes.

${ }^{16}$ Philobiblon lists two known vernacular Castilian translations of the $M V C$ : a manuscript from the last quarter of the fifteenth (BNM MSS/9560 [BETA manid 2557]) and an incunable printed at Barcelona by Peter Michael in 1493 (Library of Congress, Thacher 830 [BETA manid 2432]).
} 
text without attribution to Bonaventure. The original passage in $M V C$ belongs to an extended discussion of Mathew's account of Jesus praying on the mountain: ${ }^{17}$

Si enim uis pacienter tolerare aduersa, sis oracionis. Si uis tentaciones et tribulaciones superare, sis oracionis. Si uis prauas affecciones conculcare, sis oracionis. Si uis astucias Satane cognoscere ac euis fallacias uitare, sis oracionis. Si uis letanter uiuere in opera Dei et laboris et afficcionis non tedere, sis oracionis. Si uis in spirituali uia te exercere et carnis curam non agere in desideriis, sis oracionis. Si uis uanarum cogitacionum muscas effugare, sis oracionis. Si uis animam tuam sanctis et bonis cogitacionibus desideriis, feruoribus et deuocionibus impinguare, sis oracionis. Si uis cor tuum uirili spiritu et constanti proposito in Dei beneplacito stabilire, sis oracionis. Denique si uis uicia extirpare et uirtutibus imbui, sis oracionis. In ea enim recipitur Spritus Sancti unccio, que de omnibus mente docet. (MVC 135-36)

So if you wish to bear up patiently under adversities, be a woman of prayer. If you wish to overcome troubling temptations, be a woman of prayer. If you wish to stamp out perverse affections, be a woman of prayer. If you wish to understand the cunning of Satan and avoid his deceits, be a woman of prayer. If you wish to live happily in the work of God and not grow weary of its hardship and suffering, be a woman of prayer.

If you wish to keep yourself going to the spiritual life and not bother with fleshly desires, be a woman of prayer. If you wish to swat away the buzzing flies of fruitless thoughts, be a woman of prayer. If you wish to buttress your soul with good and holy thoughts, fervent desires and devotions, be a woman of prayer. If you wish to hold your heart steady in God's approval with courageous and unwavering spirit, be a woman of prayer. Finally if you wish to root out vices and become imbued with virtues, be a woman of prayer. For in that prayerfulness we receive the Holy Spirit's anointing, which instructs your mind about all things (JN 14:26). (Meditations 121)

These recommendations were meant to instruct a cloistered nun from the order of "Poor Clare" on the benefits of prayer within the contemplative life of an enclosed religious community. Li clearly appropriates this passage with a different purpose. He directs his words toward a lay readership seeking inwarddirected religious devotions. In this context, Michelle Karnes has characterized this type of devotion as an activity "no longer governed by and transparent to the church, devotion became much more a matter of individual prayer, meditation, and reading - the monastic trinity of oratio, meditatio, and lectio now turned popular" ("Nicholas Love" 380). By making these processes available to lay

${ }^{17}$ I cite the Latin text from Stallings-Taney's edition of $M V C$. I utilize the translation of $M V C$ by Taney et al, henceforth abbreviated as Meditations. 
readers, $\mathrm{Li}$ is seeking to harmonize the daily exercise of a secular lifestyle with the demands of spiritual disciplines as practiced in the monastery or convent where the routines of prayer and liturgy are woven into the daily life of the clergy.

The form of devotion promoted by the $M V C$ is meditation on Christ's Passion with the expressed purpose of understanding the importance of suffering within the Christian tradition. In particular, the $M V C$ urges the meditants to visualize the events of the Passion and incorporate them into the present through a form of contemplative immersion in the grisly details of Christ's torture and subsequent death:

Hoc enim inde accipe ac si dicerem: Mediteris quod ita dixit uel fecit Dominus Iesus. Et sic de smilibus. Tu autem si ex his fructum sumere cupis, ita presentem te exibeas his que per Dominum Iesum dicta et facta narrantur ac si tuis auribus audires et oculis ea uideres, toto mentis affectu diligenter, delectabiliter et morose, omnibus aliis curis et sollicitudinis tunc omissis. (MVC 10)

Regard this same as if I were to say, "Make your meditation on the Lord Jesus as if he said or did thus and so." And likewise with similar situations.

So, if you wish to profit from all this, Sister, you must place yourself in the presence of whatever is related as having been said or done by the Lord Jesus, as if you were hearing it with your own ears and seeing it with your own eyes, giving it your total mental responses: with care, delight, and sorrow, and with all extraneous cares and concerns set aside for the time being. (Meditations 4)

The $M V C$ s recommendations make the recreation of the events of the Passion a personal and individual act that transforms the devotee into a participant in its drama. Gail Gibson has argued that the $M V C$ replaced "the claims of traditional authorities with the claims of the heart" so that the devout could internalize these events and fashion an empathetic bond with Christ (10).

To the best of my knowledge, no one has noticed Li's use of the $M V C$. Delbrugge's edition of the $S d P$ does not identify the source for this passage. Li erroneously attributes this passage to Bernard: "lo que marauillosamente dela oracion escriue el glorioso bernardo " (B1r). ${ }^{18}$ Later in the $S d P$, Li cites other Church Fathers as the sources for the practices he promotes throughout his text. These include Jerome, Augustine, and Ambrose, among others, ${ }^{19}$ and refers to Gregory, for example, as a source for meditational activities: "a significar: como dize gregorio que la consideración continua dela passion y sangre de Cristo nos enciende y enflama ala batalla spiritual: y mas ardidamente nos faze vengar qualquier temptacion del diablo" (B4v-B5r). Even though Li does not refer explicitly to Bonaventure or the $M V C$, he is clearly drawing on the $M V C$ s devotional pro-

\footnotetext{
${ }^{18}$ For a discussion of the attribution of the $M V C$ to Bernard, see Karnes, Imagination 119-20.

${ }^{19}$ See Delbrugge's comments in Li, A Critical Edition 14-21.
} 
cesses. He returns regularly to the importance of Christocentric meditation: "Assi al cristiano leuar enel coraçon y enel cuerpo las señales y memoria dela santa y sagrada passion de nuestro redemptor y maestro: es bienauenturança grande y muy luzida corona" (A4v). Li in addition encourages the readers to visualize iconic elements from the Passion narrative: "como reza bernardo: los clauos dela passion sancta de mi redemptor son hechos para mi llaues muy ciertas para abrir y ver el piadoso costado con que fuemos regenerados" (H1r). Li's focus on the "clauos" and their potential for enabling the spectator/reader to become "transformed" clearly links the $S d P$ with medieval devotional guides that promoted what Jessica Boon had described as "imaginative visualizations of Christ's life [that] transform medieval devotees into spectators to the historical events of Christ's life" (9). The "clauos" referenced here suggest a link with the visualizations of those same elements in the Imago pietatis page. The interplay of the verbal with the visual, as we have noted, is one of the protocols that defines this book. By constantly directing the readers to visualize the Passion, Li is moving the $S d P$ into the devotional modes associated with routines of the $M V C$. The reflection on the virtue of Patience, while important, also becomes a tool for introducing late fifteenth-century Castilian readers to the "new" devotional style advocated by the ecclesiastical authorities.

As noted in this essay, this devotional process requires that the readers contemplate the events from the Passion story and incorporate them into their meditational activities in order to achieve a deeper understanding of the mysteries that drive Christianity:

Que la passion de jesu sea remedio de nuestros males y penas por muchas figuras nos fue prophetizado. Assi como por el serpiente de metal eleuado enel palo enel desierto: que mirando los que eran picados y feridos delas sirpientes recebian luego salud: a significar que el fijo de dios elevado enel ayre enel arbol de la vera cruz era aquel que adorado por fe y por amor hauia de guarescer las dolencias y picaduras del gran sathanas. Y contempando en su santa passion hauiamos de ser librados de toda temptacion y pecado. (B4v)

Li's text makes clear that meditations on Jesus's suffering and death on the cross were a fundamental part of being a Christian. Building on this notion, Li fashions a text whose function is to orient Castilian readers toward Christocentric meditation. For late medieval Castilian readers, then, the experience of imagining the Passion in this way promotes a modality of spirituality that emphasizes the value of empathic responses to the Passion. Ultimately, the $S d P$ creates for the readers a tool for the cultivation of new devotional practices and for their transformation into more faithful devotees of Christ.

\section{Etsi fides ex auditu, sed ex visu confirmatio est (Bernard of Clairvaux, Sermones super Cantica Canticorum [2:140])}

This study has explored how Andrés de Li incorporated Passion-centered devotional techniques into his treatise on the virtue of Christian Patience. Passion- 
centered religious practices emerged in the later Middle Ages as the principal technique used by the faithful to enrich their spiritual lives and thus attain salvation, which is the goal of all Christians. This type of Christocentric spirituality did not play a major role in most medieval treatises on Patience, where the emphasis is traditionally on exemplary sufferance by individuals facing adversity. The distinctiveness of Li's text resides in its incorporation of Passion-centered techniques within the framework of an exploration of the Christian virtue of Patience.

This type of spirituality is given prominence in the 1505 Zaragoza edition through the interplay of visual and verbal codes that encourage the readers to engage with the book in a devotional and performative manner. The primary vehicle for this Passion-centered activity is the Imago woodcut page created by the artisans of the Hurus workshop. The woodcut provides the readers with a performative script intended to evoke an empathic response to the suffering and death of Christ. The Imago page also serves as an invitation to reenact the antiphons and prayers typically performed in liturgical environments and to create through the "reading" of the image a sacred moment that alters the readers' religious self. Stocks characterizes these types of pictorial paratexts "as effective and appropriate cues for contemplation during the recitation of the familiar prayers" (16). In many religious texts of the period, pictorial content frequently functioned as a guide for the reader/spectator who sought to enrich his or her spiritual life.

In addition to the visual aspect, the $S d P$ contains abundant verbal references to the Passion and to the importance of frequent engagement with those events. In this context, it is important to understand Li's text as a tool for active contemplation of the mysteries of Christ's suffering and death on the cross. These activities, as Li observes in the closing pages of the treatise, have salvific consequences: "por quanto por el discurso de nuestra obrezilla hauemos tuuido por cierto que las tribulaciones y temptaciones suffridas con paciencia son camino seguro para meresçer la gloria bienauenturada del cielo" (H3r). The meditation and contemplation promoted in Li's book can thus be seen as a technology for effecting in the reader a change in her/his Christian self.

In conclusion, the $S d P$ successfully responded to the interests of late fifteenthcentury Castilian readers by providing them with the opportunity to engage in private, devotional performances that changed their lives. As this essay has shown, Li effectively utilized the elements of performance, specifically the functions of reader/spectator, to create a transformative experience. This experience was made possible through the medium of print which offered laypeople "ways of seeing" their faith through devotional activities centered on the suffering Christ. ${ }^{20}$

${ }^{20}$ This essay has benefited from comments by friends and colleagues. I am most grateful to Patricia Manning for her insights into early modern culture. Emily Francomano's suggestions about the social functions of early printed texts have guided my approach. Jessica Melhuse inspired me to think in new ways, and I am appreciative of her thoughtfulness and kindness. And Michael O'Brien shared his knowledge of "performance literacy" in the late medieval period. My conversations with Jessica Boon over the years have inspired me to reflect on the changes in late fifteenth-century spirituality. I also wish to thank Alberto 
W O R K S C I T E D

Amtower, Laurel. Engaging Words: The Culture of Reading in the Late Middle Ages. New York: Palgrave, 2000. Print.

Aurea expositio hymnorum. Zaragoza: Hurus, 1492. Print.

Aurea expositio hymnorum. Zaragoza: Coci, 1515-1520. Print.

Belting, Hans. Image and Its Public in the Middle Ages: Form and Function of Early Paintings of the Passion. Trans. M. Bartusis and R. Meyer. New Rochelle: Caratzas, 1990. Print.

Bernard of Clairvaux. Sancti Bernardi Opera. Ed. J. Leclercq, C. H. Talbot, and H. M. Rochais. 8 vols. Rome: Editiones Cistercienses, 1957-77. Print.

Bertelli, Carlo. "The Image of Pity in Santa Croce in Gerusalemme." Essays in the History of Art Presented to Rudolf Wittkower. Ed. Douglas Fraser, Howard Hibard, and Milton J. Lewine. London: Phaidon, 1967. 40-55. Print.

Bestul, Thomas. Texts of the Passion: Latin Devotional Literature and Medieval Society. Philadelphia: U of Pennsylvania P, 1996. Print.

Boon, Jessica. The Mystical Science of the Soul: Medieval Cognition in Bernardino de Laredo's Recollection Method. Toronto: U of Toronto P, 2012. Print.

Brantley, Jessica. Reading in the Wilderness: Private Devotion and Public Performance in Late Medieval England. Chicago: U of Chicago P, 2007. Print.

Bryan, Jennifer. Looking Inward: Devotional Reading and the Private Self in Late Medieval England. Philadelphia: U of Pennsylvania P, 2008. Print.

Bynum, Caroline Walker. "Violent Imagery in Late Medieval Piety." GHI Bulletin 30 (2002): 3-36. Print.

Carruthers, Mary. The Book of Memory: A Study in Medieval Culture. Cambridge: Cambridge UP, 1990. Print.

- The Craft of Thought: Meditation, Rhetoric, and the Making of Images, 400-1200. Cambridge: Cambridge UP, 2000. Print.

Catholic Church. Officia quotidiana, sive Horae cuiuslibet dei. Zaragoza: Jorge Coci, Leonardo Hutz, and Lope Appenteger, 1500. Print.

Chartier, Roger. "Introduction." The Culture of Print: Power and the Uses of Print in Early Modern Europe. Princeton: Princeton UP, 1989. 1-9. Print.

—. "The Practical Impact of Writing." A History of Private Life. Vol 3. Ed. Roger Chartier. Trans. Arthur Goldhammer. Cambridge: Belknap, 1989. 111-59. 1991. Print.

Clark, Robert and Pamela Sheingorn. "Performative Reading: The Illustrated Manuscripts of Arnoul Gréban's Mystère de la Passion.” European Medieval Drama 6 (2002): 129-72. Print.

Cyprian, Bishop of Carthage. De bono patientiae. Ed. and trans. M. George Edward Conway. Washington, D.C.: Catholic UP, 1957. Print.

Delbrugge, Laura. Introduction. Li, A Critical Edition 1-3.

Despres, Denise. Ghostly Sights: Visual Meditation in Late Medieval Literature. Norman: Pilgrim, 1989. Print.

Duffy, Eamon. Marking the Hours: English People and Their Prayers 1240-1570. New Haven: Yale UP, 2006. Print.

- Stripping of the Altars: Traditional Religion in England, c. 1400-c.1580. New Haven: Yale UP, 1992. Print.

Faulhaber, Charles B., et al., eds. PhiloBiblon: Electronic Bibliographies of Medieval Catalan, Galician, Portuguese, and Spanish Texts. Bancroft Library, University of California, Berkeley, 1997-2014. Web. 2 Feb. 2013.

Flora, Holly. The Devout Belief of the Imagination: The Paris Meditationes Vitae Christi and Female Franciscan Spirituality in Trecento Italy. Turnhout: Brepols, 2009. Print.

Foucault, Michel. "Technologies of the Self." Technologies of the Self: A Seminar with Michel

Montaner and George Greenia for help in obtaining the digital images of the $S d P$. I also express my gratitude to the anonymous evaluators for this journal, whose insights were helpful in the preparation of this study. Finally, Charles A. Rivera pointed me in the right direction, and Cynthia kindly saved me from numerous mistakes. For those errors that remain, I alone am responsible. 
Foucault. Ed. Luther Martin, Huck Gutman, and Patrick Hutton. Amherst: U of Massachusetts P, 1988. 16-49. Print.

Freedberg, David. The Power of Images: Studies in the History and Theory of Response. Chicago: U of Chicago P, 1989. Print.

Fulton, Rachel. From Judgment to Passion: Devotion to Christ and the Virgin Mary, 800-1200. New York: Columbia UP, 2003. Print.

Gibson, Gail McMurray. Theater of Devotion: East Anglian Drama and Society in the Late Middle Ages. Chicago: U of Chicago P, 1989. Print.

Griffin, Clive. "Celestina's Illustrations." Bulletin of Hispanic Studies 78 (2001): 59-79. Print.

Gründler, Otto. "Devotio moderna." Christian Spirituality: High Middle Ages and Reformation. Ed. Jill Riatt. New York: Crossroad, 1988. 176-93. Print.

Hanna, Ralph. "Some Commonplaces of Late Medieval Patience Discussions: An Introduction." The Triumph of Patience: Medieval and Renaissance Studies. Ed. Gerard J. Schiffhorst. Orlando: UP of Florida, 1978. 65-87. Print.

Hauerwas, Stanley and Charles Pinches. "Practicing Patience: How Christians Should Be Sick." Christian Bioethics 2 (1996): 202-21. Print.

The Holy Bible: Douay Rheims Version. Charlotte: Saint Benedict, 2013. Print.

Illich, Ivan. In the Vineyard of the Text: A Commentary to Hugh's Didascalicon. Chicago: U of Chicago P, 1993. Print.

Johannes de Caulibus. Meditaciones vite Christi. Ed. M. Stallings-Taney. CCCM 153. Turnhout: Brepols, 1997. Print.

John of Caulibus. Meditations on the Life of Christ. Trans. and ed. Francis X. Taney, Sr, Anne Miller, and C. Mary Stallings-Taney. Asheville: Pegasus, 2000. Print.

Karnes, Michelle. Imagination, Meditation and Cognition in the Middle Ages. Chicago: U of Chicago P, 2011. Print. Print

La passion del eterno principe. Burgos: Fadrique de Basilea, 1493. Print.

Lehfeldt, Elizabeth A. Religious Women in Golden Age Spain: The Permeable Cloister. Hampshire: Ashgate, 2005. Print.

Lewis, Flora. "Rewarding Devotion: Indulgences and the Promotion of Images." Studies in Church History 28 (1992): 179-94. Print.

Li, Andrés de. A Critical Edition of Andrés de Li's Summa de Paciencia (1505): With Introduction, Notes, and Textual History. Ed. Laura Delbrugge. Lewiston: Mellen, 2003. Print.

. A Scholarly Edition of Andrés de Li's Thesoro de la passion (1494). Ed. Laura Delbrugge. Leiden: Brill, 2011. Print.

- Summa de paciencia. Zaragoza: Pablo Hurus, 1493. Print.

-. Summa de paciencia. Zaragoza: Jorge Coci, 1505. Print.

- Thesoro dela passion sacratissima de nuestro redemptor. Zaragoza: Hurus, 1494. Print.

Lucía Megías, José Manuel. Imprenta y libros de caballerías. Madrid: Ollero \& Ramos, 2000. Print.

Mâle, Emile. Religious Art in France: The Late Middle Ages. Trans. Marthiel Mathews. Princeton: Princeton UP, 1986. Print.

Marrow, James H. Passion Iconography in Northern European Art of the Late Middle Ages and Early Renaissance: A Study of the Transformation of Sacred Metaphor into Descriptive Narrative. Kortrijk: Van Ghemmert, 1979. Print.

McNamer, Sarah. Affective Meditation and the Invention of Medieval Compassion. Philadelphia: U of Pennsylvania P, 2010. Print.

—. "The Origins of the Meditationes Vitae Christi." Speculum 84 (2009): 905-55. Print.

Meany, Mary. "The Meditaciones vite Christi as a Book of Prayer." Franciscan Studies 64 (2006): 217-34. Print.

Mills, David. “' Look at Me When I'm Speaking to You': The 'Behold and See' Convention in Medieval Drama." Medieval English Theatre 7 (1985): 4-12. Print.

O'Kane, Martin. "Picturing 'The Man of Sorrows': The Passion-Filled Afterlives of a Biblical Icon." Religion and the Arts 9 (2005): 62-100. Print.

Parshall, Peter. "The Art of Memory and the Passion." Art Bulletin 81 (1999): 456-72. Print. 
"Imago Contrafacta: Images and Facts in the Northern Renaissance." Art History 16 (1993): 554-79. Print.

Pedraza Gracia, Manuel José. Documentos para el estudio de la historia del libro en Zaragoza entre 1501 y 1521. Zaragoza: Centro de Documentación Bibliográfica, 1993. Print.

Peña, Manuel. Cataluña en el Renacimiento: libros y lenguas (Barcelona, 1473-1600). Lleida: Milenio, 1996. Print.

Pereda, Felipe. Las imágenes de la discordia: política y poética de la imagen sagrada en la España del 400. Madrid: Marcial Pons, 2007. Print.

Petersen, Nils Holger. "Liturgical Representation and Late Medieval Piety." Liturgy and the Arts in the Middle Ages: Studies in Honour of C. Clifford Flanigan. Ed. Eva Louise Lillie and Nils Holger Petersen. Copenhagen: Museum Tusculanum, 1996. 181-204. Print.

Robinson, Cynthia. Imagining the Passion in a Multiconfessional Castile: The Virgin, Christ, Devotions, and Images in the Fourteenth and Fifteenth Centuries. University Park: Penn State UP, 2013. Print.

"Preaching to the Converted: Valladolid's Cristianos nuevos and the Retablo de don Sancho de Rojas (1415)." Speculum 83 (2008): 112-63. Print.

Sterponi, Laura. "Reading and Meditation in the Middle Ages: Lectio Divina and Books of Hours." Text E Talk 28 (2008): 667-89. Print.

Stevenson, Jill. Performance, Cognition Theory, and Devotional Culture: Sensual Piety in Late Medieval York. New York: Palgrave, 2010. Print.

Stock, Brian. The Implications of Literacy: Written Language and Models of Interpretation in the Eleventh and Twelfth Centuries. Princeton: Princeton UP, 1983. Print.

Stocks, Bronwyn. "Text, Image and a Sequential 'Sacra Conversazione' in Early Italian Books of Hours." Word and Image 23 (2007): 16-24. Print.

Swanson, Robert N. "Praying for Pardon: Devotional Indulgences in Late Medieval England." Promissory Notes on the Treasury of Merits: Indulgences in Late Medieval Europe. Ed. R. N. Swanson. Leiden: Brill, 2006. 214-40. Print.

Talavera, Fray Hernando de. Católica impugnación. Ed. Francisco Martín Hernández. Barcelona: Juan Flors, 1961. Print.

Turner, Victor. The Anthropology of Performance. New York: PAJ, 1986. Print.

Waugh, Robin. The Genre of Medieval Patience Literature: Development, Duplication, and Gender. New York: Palgrave, 2012. Print.

Woolf, Rosemary. The English Religious Lyric in the Middle Ages. Oxford: Oxford UP, 1968. Print. 
Reproduced with permission of the copyright owner. Further reproduction prohibited without permission. 